\title{
A new Xenacanthiformes shark (Chondrichthyes, Elasmobranchii) from the Late Paleozoic Rio do Rasto Formation (Paraná Basin), Southern Brazil
}

\author{
VICTOR E. PAULIV ${ }^{1,2}$, ELISEU V. DIAS $^{3}$, FERNANDO A. SEDOR $^{2}$ and ANA MARIA RIBEIRO ${ }^{4}$ \\ ${ }^{1}$ Programa de Pós-Graduação em Geociências, Instituto de Geociências, \\ Universidade Federal do Rio Grande do Sul, 91501-970 Porto Alegre, RS, Brasil \\ ${ }^{2}$ Museu de Ciências Naturais, Setor de Ciências Biológicas, Universidade Federal do Paraná, \\ Centro Politécnico, Jardim das Américas, 81531-990 Curitiba, PR, Brasil \\ ${ }^{3}$ Laboratório de Geologia e Paleontologia, Centro de Ciências Biológicas e da Saúde, \\ Universidade Estadual do Oeste do Paraná, 85819-110 Cascavel, PR, Brasil \\ ${ }^{4}$ Museu de Ciências Naturais, Fundação Zoobotânica do Rio Grande do Sul, 90690-000 Porto Alegre, RS, Brasil
}

Manuscript received on July 6, 2012; accepted for publication on June 4, 2013

\begin{abstract}
The Brazilian records on Xenacanthiformes include teeth and cephalic spines from the Parnaíba, Amazonas and Paraná basins. This work describes a new species of Xenacanthidae, collected in an outcrop of Serrinha Member of Rio do Rasto Formation (Wordian to Wuchiapingian), Paraná Basin, municipality of Jacarezinho, State of Paraná. The teeth of the new species are two or three-cuspidated and the aboral surface show a smooth concavity and one rounded basal tubercle. The coronal surface presents one semispherical and subcircular coronal button, and also two lateral main cusps and one central (when present) with less than one fifth of the size of the lateral cusps in the labial portion. The lateral cusps are asymmetric or symmetric, rounded in transversal section, lanceolate in longitudinal section, devoid of lateral carinae and lateral serrations, and with few smooth cristae of enameloid. In optical microscope the teeth show a trabecular dentine (osteodentine) base, while the cusps are composed by orthodentine, and the pulp cavities are non-obliterated by trabecular dentine. The fossil assemblage in the same stratigraphical level and in the whole Rio do Rasto Formation indicates another freshwater record for xenacanthid sharks.
\end{abstract}

Key words: Permian, Xenacanthimorpha, Xenacanthidae, Xenacanthus, shark teeth.

\section{INTRODUCTION}

The Xenacanthiformes (from gr. xenos $=$ strange + lat. acanthos $=$ spine) are represented by sharks with narrow and fusiform body shapes (Moy-Thomas and Miles 1971), which were common throughout the world in the Middle to Late Paleozoic and Early Mesozoic (Long 2011), ranging from the Lower Carboniferous to the Upper Triassic of shallowwater marine, marginal and freshwater deposits

Correspondence to: Victor Eduardo Pauliv

E-mail:vpauliv@gmail.com
(Hampe 2003, Turner and Burrow 2011). These sharks are known by their few articulated skeletons and, mainly by cephalic spines and characteristic diplodont teeth with two lateral cusps usually larger than the median one (Ginter 2004).

In Brazil, the xenacanthiforms are recorded in the Amazonas, Parnaíba and Paraná basins. In the Amazonas Basin they occur in the Itaituba Formation (Duffin et al. 1996). In the Parnaíba Basin the group occurs in the Pimenteiras (Alves et al. 2008a) and Pedra de Fogo formations (e.g. Silva-Santos 1946, 
Silva-Santos and Salgado 1970, Alves et al. 2008a, b, Souza et al. 2008, Alves 2010). In the Paraná Basin these sharks are found in the transition between Tatuí to Irati formations (Ragonha 1978, Chahud and Petri 2008), Irati Formation (Würdig-Maciel 1975, Chahud and Petri 2009, 2010), Corumbataí Formation (Ragonha 1984a, 1986, 1989a, Toledo et al. 2005, Campanelli and Fernandes 2008), Terezina Formation (Würdig-Maciel 1975, Richter 2005) and Rio do Rasto Formation (Ragonha 1989b, 1990, Dias 1996, Figueiredo et al. 2008, Pauliv et al. 2010). The Corumbataí Formation is currently equivalent to the Serra Alta and Terezina formations (Rohn 2001, Holz et al. 2010) so the records of these formations should be merged. In spite of all these records mentioned above, xenacanthiforms are poorly known in South America and xenacanthid teeth from the Serrinha Member of Rio do Rasto Formation (Paraná State) reported by Pauliv et al. (2010) are detailed in this contribution.

The Rio do Rasto Formation was divided by Gordon Jr. (1947) into two members, the Serrinha Member (inferior) and the Morro Pelado Member (superior) and is considered by Holz et al. (2010) as Wordian to Wuchiapingian (Permian).

Some paleoenvironmental interpretations were proposed for the Rio do Rasto Formation. For the Serrinha Member the majority of these interpretations suggest a shallow lacustrine environment (e.g. Mendes 1967, Ragonha 1989b, Lavina 1991) and for Holz et al. (2010) these shallow lakes were sometimes influenced by storm waves and fluvial incursions. For the Morro Pelado Member, Lavina (1991) and Holz et al. (2010) considered them as sedimentary deposits of smaller lakes, alluvial plains, fluvial meandering streams, delta systems with interdistributary bays, as well as small temporary water bodies. The paleoenvironmental interpretations mentioned above are supported by the floristic and faunistic records, and the presence of conchostraceans indicates a freshwater condition to the whole Rio do Rasto Formation (Holz et al. 2010).

\section{MATERIALS AND METHODS}

The material corresponds to teeth collected from an outcrop of the Serrinha Member of Rio do Rasto Formation in the northeastern region of the State of Paraná, municipality of Jacarezinho, near kilometer 20, west margin of the BR-153 federal highway, coordinates: $23^{\circ} 10^{\prime} 08^{\prime \prime} \mathrm{S}$ and $49^{\circ} 57^{\prime} 49^{\prime \prime} \mathrm{W}$ (Figure 1). The studied material are housed in the paleontological collection of the Museu de Ciências Naturais at the Setor de Ciências Biológicas of Universidade Federal do Paraná (MCN-SCB-UFPR) in Curitiba, Paraná, under the numbers MCN.P.453, MCN.P.1088, MCN.P.1089, MCN.P.1090, MCN.P.1091 and thin sections numbers MCN.P.1125, MCN.P.1126a, MCN.P.1126b and MCN.P. 1127. All specimens were collected associated with other fish remains such as actinopterygian scales and teeth. The specimen MCN.P.1088, was associated with a shark finspine ascribed to a new species of Sphenacanthus (Pauliv et al. 2009, 2012).

The type series of Xenacanthus santosi and $X$. pricei Würdig-Maciel, 1975 housed in the Micropaleontology collection of the Instituto de Geociências of the Universidade Federal do Rio Grande do Sul (IGeo-UFRGS), Porto Alegre, Brazil; and Wurdigneria obliterata Richter, 2005 housed in the Museu de Ciências e Tecnologia of the Pontifícia Universidade Católica do Rio Grande do Sul (MCT-PUCRS), Porto Alegre, Brazil, were analyzed for comparison.

The preparation of the specimens was done under stereomicroscope using mechanical techniques with steel tips. The samples were impregnated with polystyrene dissolved in xylol increasing teeth resistance. The samples were photographed with Olympus SZX9 stereomicroscope of Laboratório de Microtécnica of the Universidade Positivo, Curitiba, Brazil and with Zeiss Discovery.V20 stereomicroscope of Laboratório de Foraminíferos e Micropaleontologia Ambiental (LaFMA-UFPR), Curitiba, Brazil. 


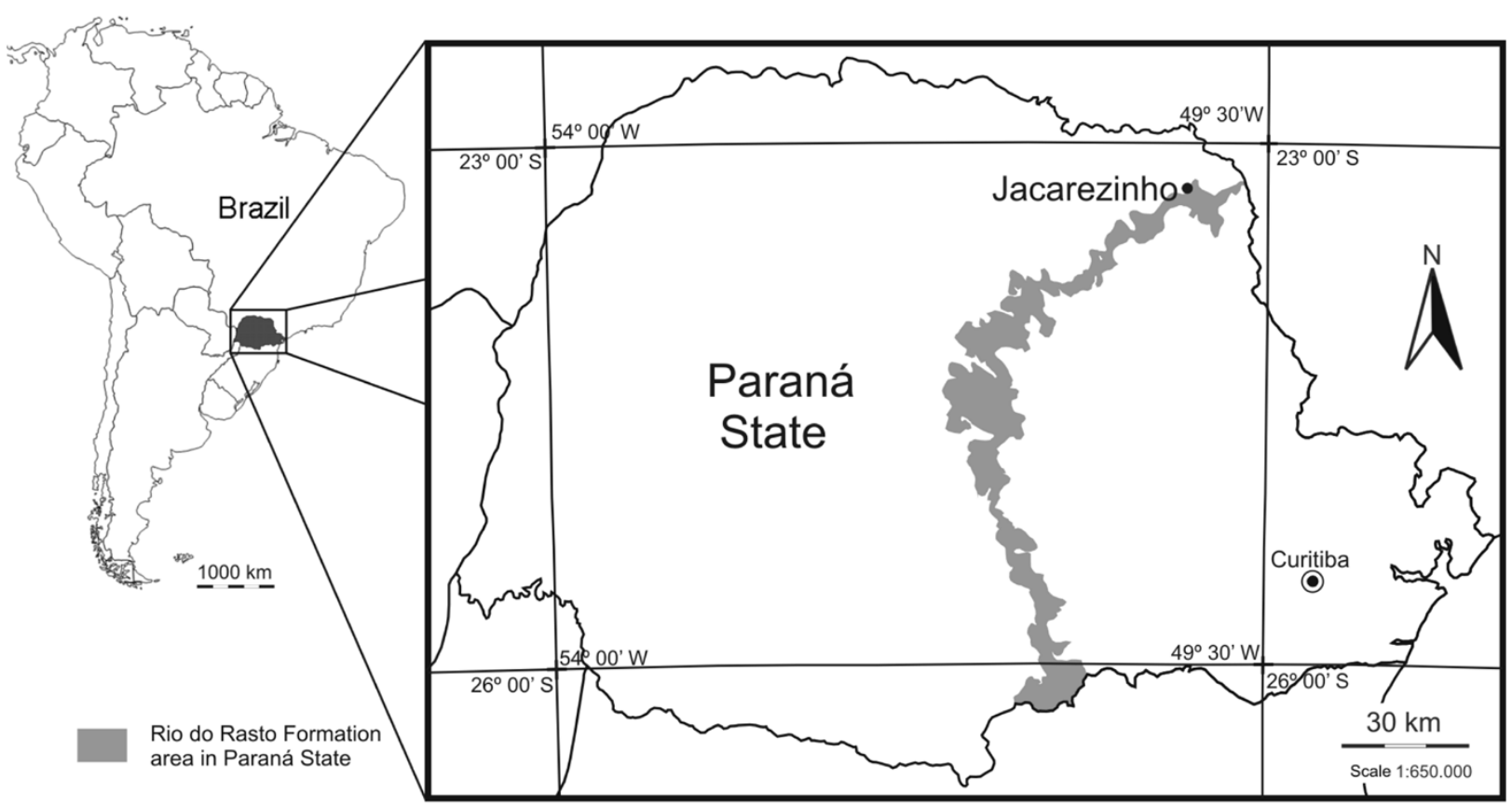

Figure 1 - Distribution of the Rio do Rasto Formation in the State of Paraná with the location of the collecting site in the municipality of Jacarezinho (modified from Mineropar, 2006).

Some of the specimens were thin-sectioned using epoxi 324 resin to include the material and abrasive materials. These sections were photographed in the Fundação Zoobotânica do Rio Grande do Sul, Porto Alegre (MCN-FZB-RS) using the Zeiss Axiovert 40 CFL and in the Universidade Estadual do Oeste do Paraná (Unioeste), Cascavel, (Laboratório de Foto Microscopia) using the Olympus BX-60 microscope.

The anatomical nomenclature was based on Ragonha (1984a), Johnson (1999), Hampe (2003), Richter (2005) and Ginter et al. (2010).

\section{SYSTEMATICS}

Class Chondrichthyes Huxley, 1880

Subclass Elasmobranchii Bonaparte, 1838

Order Xenacanthiformes (= Xenacanthida) Berg, 1937

Family Xenacanthidae Fritsch, 1889

Genus Xenacanthus Beyrich, 1848

Type species: Xenacanthus decheni Goldfuss 1847

Xenacanthus ragonhai $\mathrm{sp}$. nov.

Figures 2-4
Etymology. In honor of Evaldo Wehmuth Ragonha, the Brazilian Paleoichthyologist who studied the Xenacanthiformes from the Paraná Basin during the 1970, 1980 and 1990's.

Holotype: MCN.P.1088 a tooth.

Paratype. The isolated teeth MCN.P.453, MCN.P.1089, MCN.P.1090, MCN.P.1091 and thin sections MCN.P.1125, MCN.P.1126a, MCN.P.1126b, MCN.P.1127.

Type locality and horizon. Serrinha Member of the Rio do Rasto Formation (Wordian to Wuchiapingian according to Holz et al. 2010), Passa Dois Group, Paraná Basin, municipality of Jacarezinho, northeastern region of the State of Paraná, South Brazil.

Diagnosis. Chondrichthyans only known by tricusp or less frequently bicuspid teeth with the following combination of features: teeth with two lateral main cusps and one central (when present) around one fifth $(1 / 5)$ of the lateral ones; lateral cusps lanceolate without lateral carinae and rounded 
in transversal section; thin enameloid present; few smooth cristae of enameloid on the lateral cusps; teeth base composed of trabecular dentine (osteodentine) while the cusps are composed by orthodentine; trabecular dentine overlaps externally the orthodentine on the basal portion of the lateral cusps; pulp cavity non-obliterated by trabecular dentine; coronal button sub-circular and semispherical in shape and sometimes extend among the lateral cusps; coronal button presents a prominent edge and the connection to the base presents a small notch around and by a wide shaft.

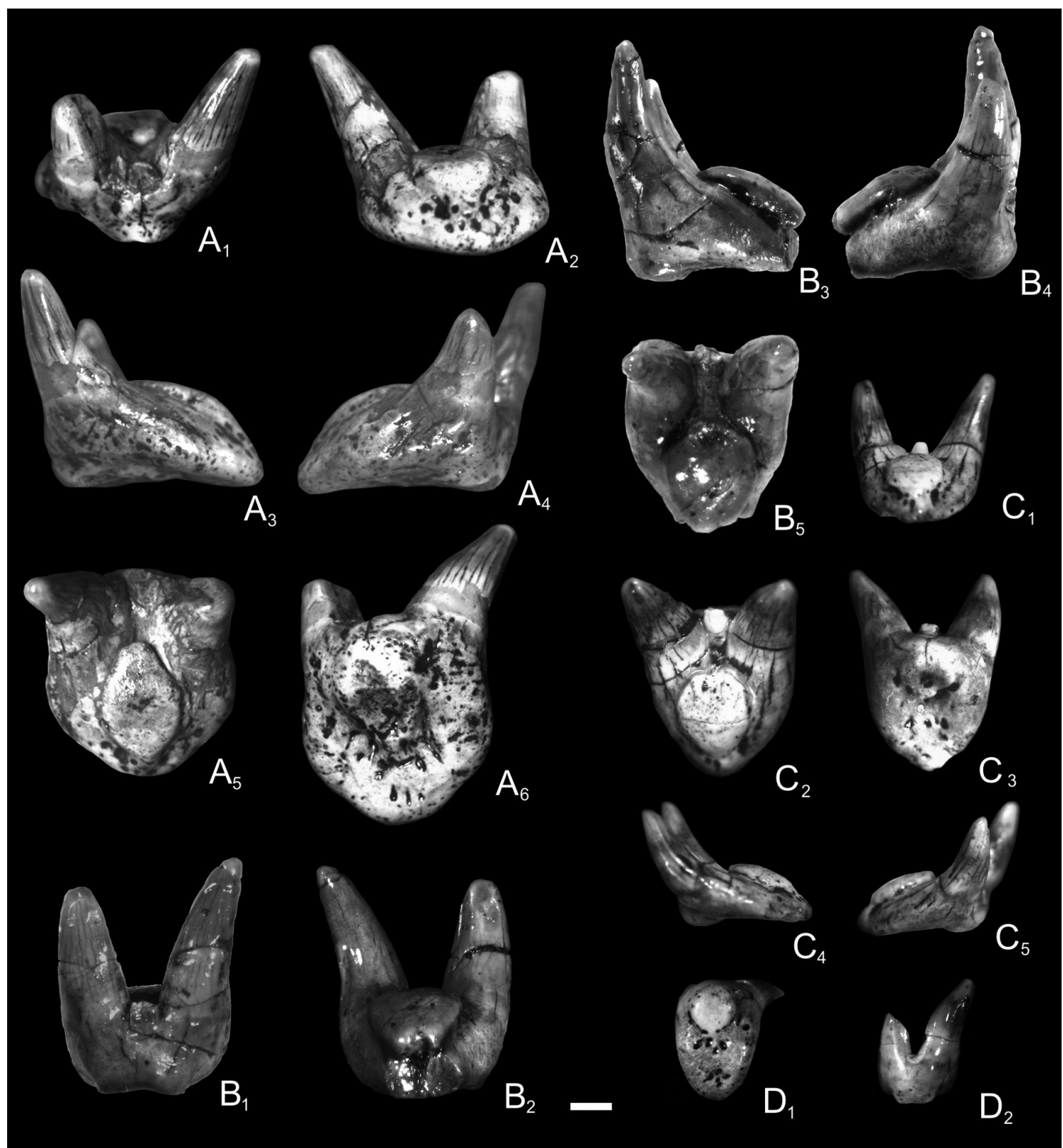

Figure 2 - Xenacanthus ragonhai sp. nov. from the Rio do Rasto Formation, Wordian to Wuchiapingian, Brazil. A: specimen MCN.P.1088 (holotype), labial $\left(A_{1}\right)$, lingual $\left(A_{2}\right)$, laterals $\left(A_{3}\right.$ and $\left.A_{4}\right)$, aboral $\left(A_{5}\right)$ and coronal $\left(A_{6}\right)$ views respectively; $\mathbf{B}$ : specimen MCN.P.453 (paratype), labial $\left(\mathrm{B}_{1}\right)$, lingual $\left(\mathrm{B}_{2}\right)$, laterals $\left(\mathrm{B}_{3}\right.$ and $\left.\mathrm{B}_{4}\right)$ and aboral $\left(\mathrm{B}_{5}\right)$ views; $\mathrm{C}$ : specimen MCN.P.1089 (paratype), lingual $\left(\mathrm{C}_{1}\right)$, laterals $\left(\mathrm{C}_{2}\right.$ and $\left.\mathrm{C}_{3}\right)$, aboral $\left(\mathrm{C}_{4}\right)$ and coronal $\left(\mathrm{C}_{5}\right)$ views respectively; D: specimen MCN.P.1091 (paratype), lingual $\left(D_{1}\right)$ and aboral $\left(D_{2}\right)$ views respectively. Scale bar $=1 \mathrm{~mm}$. 


\section{DESCRIPTION}

Xenacanthus ragonhai sp. nov. presents teeth with three cusps (MCN.P.453, MCN.P.1089, MCN.P.1125 and MCN.P.1127) or rarely two cusps (MCN.P.1091), in which the two main cusps are lateral and bigger than the third central one, which is typically reduced or absent for xenacanthid teeth (Figure 2). In X. ragonhai sp. nov. some teeth have reductions of the central cusp due to a taphonomical process that breaks it or to occlusal wearing, that makes these teeth secondarily bicusps (MCN.P.1088, MCN.P.1089, MCN.P.1090). When present, the central cusp is less than one fifth of the lateral ones. The teeth vary in size between $3 \mathrm{~mm}$ to $5.5 \mathrm{~mm}$ in length, 2.5 to $5 \mathrm{~mm}$ in width and 3 to $6.5 \mathrm{~mm}$ in height.

In aboral view, the teeth base is slightly concave and almost rounded (Figure 2 $\mathrm{A}_{5}$ ) or oval shaped (Figure $2 \mathrm{D}_{1}$ ), with several foramina predominantly arranged around the basal tubercle. The basal tubercle is also rounded and well developed occupying about one third of this surface and is located close to the labial edge. In coronal view the base presents a coronal button, also known as apical button. In $X$. ragonhai sp. nov. this structure is subcircular, semi-spherical and sometimes, almost flat at the top. The coronal button presents a notch around the connection with the base (Figures $2 \mathrm{~B}_{2}-\mathrm{B}_{4}$ ), except in the lingual portion, in which there is a wide shaft (Figures $\mathrm{A}_{3}-\mathrm{A}_{4}, \mathrm{C}_{4}-\mathrm{C}_{5}$ ). Small foramina on the coronal button surface are present, as well as around the notch, and bigger foramina are present along the lingual edge of the base.

The crown can be tricusp or bicusp as already mentioned, with two major lateral cusps, the mesial and distal ones, while the smaller is the central cusp, between the two lateral ones. The lateral cusps are devoid of carinae, rounded proximally, and present a lanceolate longitudinal cross-section. These cusps possess similar or unequal sizes, and this inequality is interpreted as different anatomic positions or, in some cases, as a result of the cusps wearing stage. This wearing could be related to the taphonomical abrasion or due to the contact with the opposite teeth during feeding, causing an occlusal wearing, as observed in the specimens MCN.P.1088 and MCN.P.1090. The occlusal wearing of MCN.P.1088 is indicated by chamfers on the lateral distal portion of the base (Figure $2 \mathrm{~A}_{4}-\mathrm{A}_{5}$, Figure $3 \mathrm{~A}_{1}-3 \mathrm{~A}_{3}$ ) and on the labial surface of the mesial cusp (Figures 2 $\mathrm{A}_{2}$, $2 \mathrm{~A}_{6}$; Figure $3 \mathrm{~A}_{4}$ ) in addition to the wearing of the central cusp. In the specimen MCN.P.1090, the occlusal wearing evident in the internal surface of the mesial cusp forming a chamfer, and totally consumed the central cusp and reaching the base of the distal cusp internally, making a concavity between the two main cusps (Figures $3 \mathrm{~B}_{1}-3 \mathrm{~B}_{2}$ ).

The lateral cusps are relatively asymmetric in labial view (MCN.P.453, MCN.P.1088, MCN.P.1090, MCN.P.1091) or almost symmetric (MCN.P.1089, MCN.P.1125, MCN.P.1127) indicating heterodont condition in Xenacanthus ragonhai sp. nov. similar with the specimens described by Hampe (1988). Thus the asymmetric specimens mentioned above are interpreted here as lateral teeth since the lateral main cusps are slightly inclined, while the almost symmetric specimens are interpreted as mesial teeth. The specimen MCN.P.1091 is interpreted as posterior due to being a small tooth and due to the absence of the central cusp.

\section{Histological Aspects}

The Xenacanthus ragonhai $\mathrm{sp}$. nov. teeth base are composed by trabecular dentine (= osteodentine) while the cusps are made up of an orthodentine (Figure $4 \mathrm{~A}_{1}$ ). In longitudinal cross-section the cusps are composed by concentric orthodentine layers with a central pulpar cavity (Figures $4 \mathrm{~A}_{1}$, $\left.\mathrm{B}_{1}, \mathrm{C}, \mathrm{D}\right)$. The pulpar cavity is non-obliterated by trabecular dentine, extending from the cusp base until its apical portion and could present a small projection of trabecular dentine as seen 

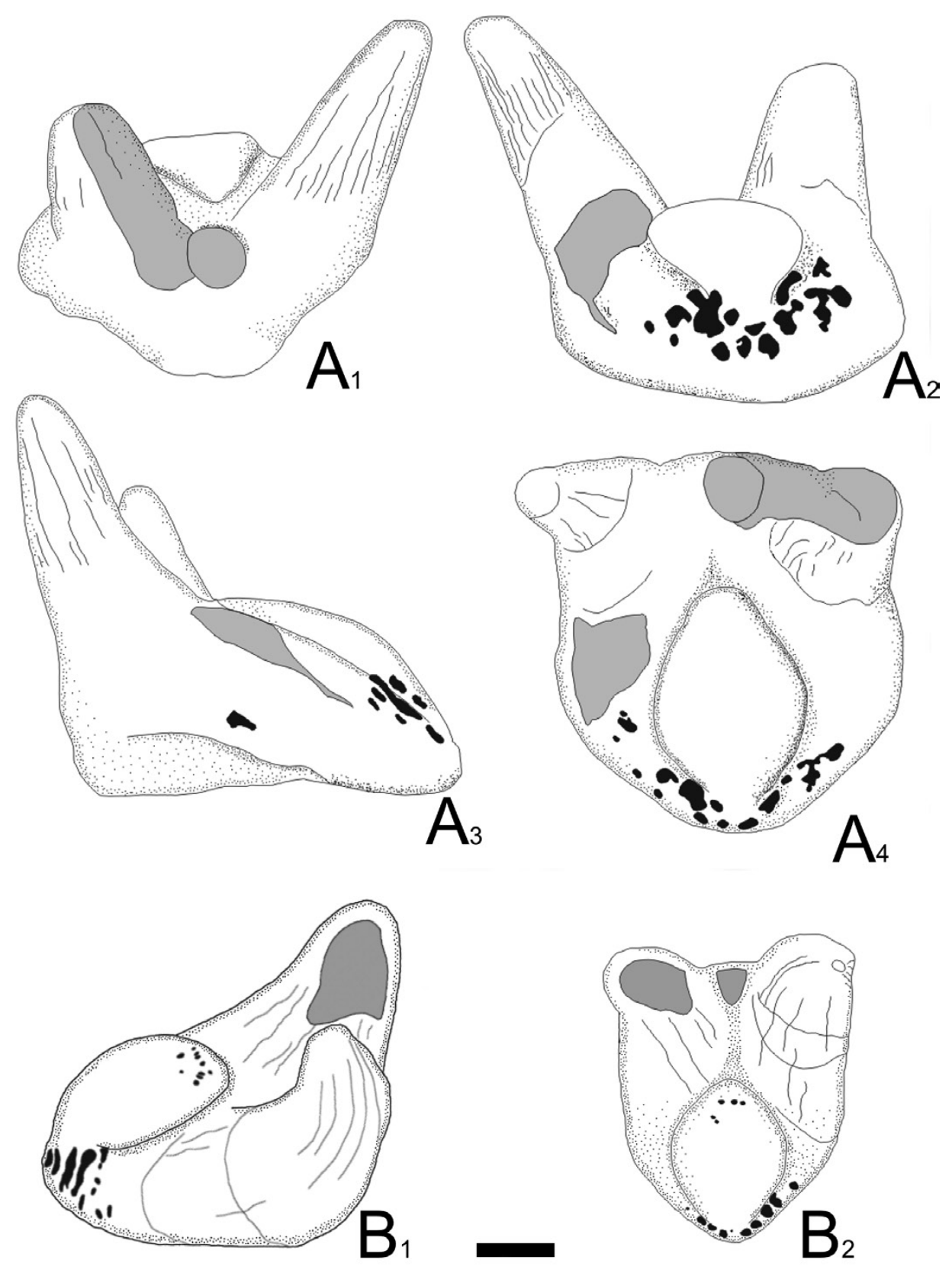

Figure 3 - Xenacanthus ragonhai sp. nov. from the Rio do Rasto Formation, Wordian to Wuchiapingian, Brazil. A: MCN.P.1088 (holotype), labial $\left(A_{1}\right)$, lingual, $\left(A_{2}\right)$, lateral $\left(A_{3}\right)$ and coronal $\left(A_{4}\right)$ views respectively; B: MCN.P.1090 (paratype) latero-oclusal $\left(B_{1}\right)$ and occlusal $\left(B_{2}\right)$ views respectively. Gray areas represent occlusal wearing on the lateral distal portion of the base, on the labial surface of the mesial cusp (MCN.P.1088), on the lateral medial portion of the mesial cusp and on the central cusp (MCN.P.1090). Scale bar $=1 \mathrm{~mm}$.

in Figure 4C. On the tooth base, the trabecular dentine overlaps externally the orthodentine on the basal portion of lateral cusps (similar to that seem in Lebachacanthus senkenbergianus Hampe
1991). In X. ragonhai sp. nov. the lateral cusps are covered with a thin enameloid layer (Figure $4 \mathrm{~B}_{2}$ ), and this layer forms a few smooth cristae of enameloid on the lateral cusps (Figure $4 \mathrm{~B}_{2}$ ). 

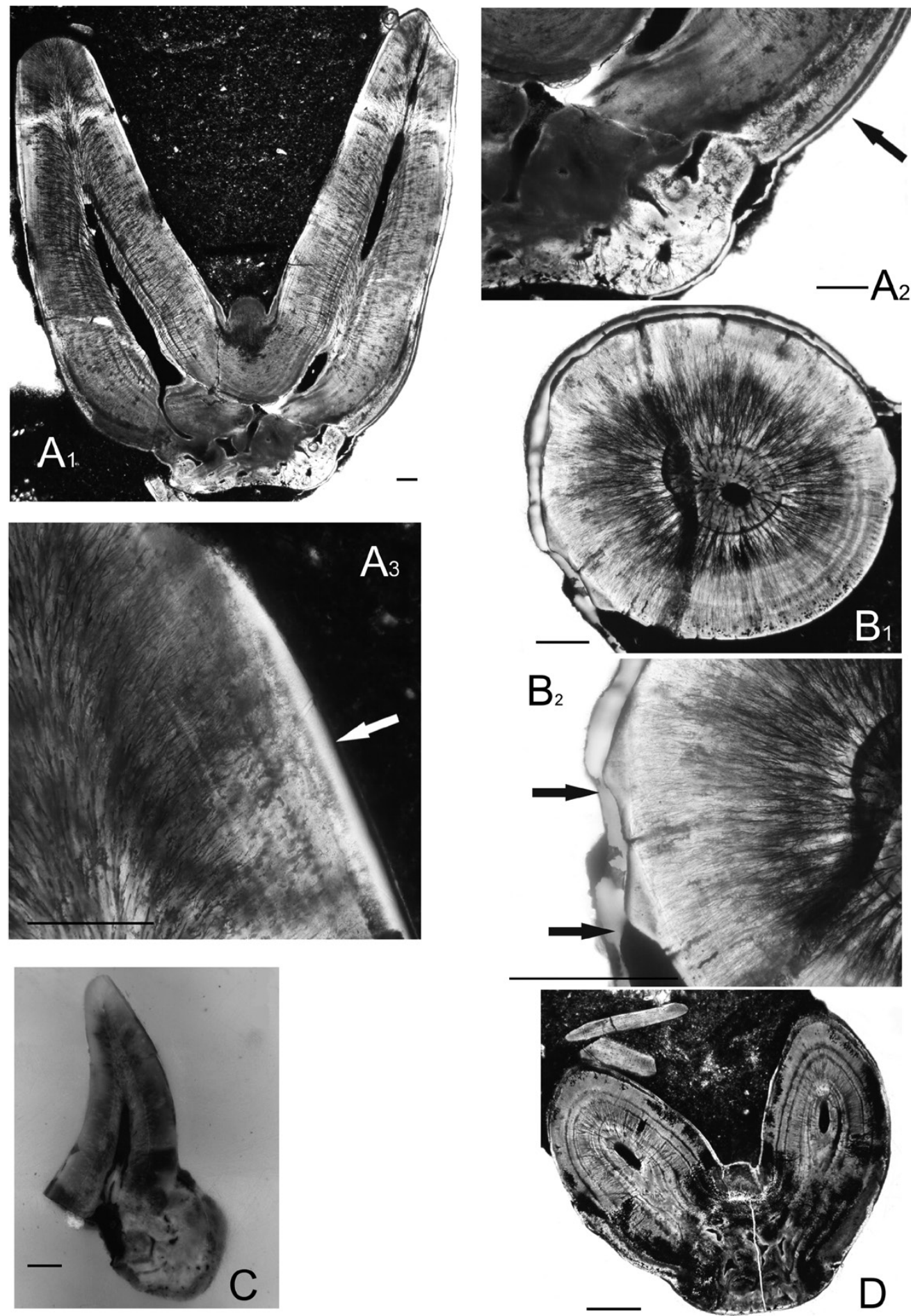

Figure 4 - Xenacanthus ragonhai sp. nov. from the Rio do Rasto Formation, Wordian to Wuchiapingian, Brazil teeth histology. A, MCN.P.1125, $\mathrm{A}_{1}$ : longitudinal section through the lateral cusps, $\mathrm{A}_{2}$ : arrow points to the trabecular dentine overlaping externally to the orthodentine on the basal portion of lateral cusps, $\mathrm{A}_{3}$ : arrow points to a detail of the thin enameloid layer; B, MCN.P.1126a, transversal section through a lateral cusp $\left(\mathrm{B}_{1}\right)$ and the arrow points to the few smooth cristae of enameloid ( $\left.\mathrm{B}_{2}\right), \mathrm{C}, \mathrm{MCN} . \mathrm{P} .1126 \mathrm{~b}$, polished section through a lateral cusp showing a small projection of trabecular dentine; D, MCN.P.1127, obliquous longitudinal section through a teeth Scale bars A-B $=200 \mu \mathrm{m} C-\mathrm{D}=500 \mu \mathrm{m}$. 


\section{DISCUSSION AND CONCLUSIONS}

According to Zangerl (1981) the Order Xenacanthiformes is represented by sharks with a fusiform body shape, one dorsal spine and teeth modified from the cladodont design, in which the lateral cusps are enhanced and the central cusp is slender, small or even absent. These features are present in the studied teeth indicating that they belong to this order. Following Hampe (2003) and Ginter et al. (2010), this order is divided into two families: Diplodoselachidae and Xenacanthidae. These authors mentioned that Xenacanthidae teeth show non-serrated lateral edges on the cusps, cusps often equipped with vertical cristae and basal tubercle always with a concave depression. The studied specimens present all these features, so they are attributed to the Family Xenacanthidae.

Ginter et al. (2010) mentioned that five genera are included in the Xenacanthidae: Plicatodus Hampe 1995, Triodus Jordan 1849, Mooreodontus Ginter et al. 2010 Wurdigneria, Richter 2005 and Xenacanthus Beyrich 1848.

Based on the summary of Plicatodus presented by Ginter et al. (2010), Xenacanthus ragonhai differs from this genus. Plicatodus have cusps with elliptical cross-section near the base; lateral cusps curved sigmoidally throughout their apical portion; surface of the cusps exhibiting a pattern of generally strong, wavy or curved vertical cristae; elliptical shaped base; small coronal button; base and crown consisting almost entirely of orthodentine and by the absence of enameloid.

The new species also resemble the teeth features presented by Ginter et al. (2010) to the Triodus genus. However, the crown and the base of Triodus teeth are almost entirely composed by orthodentine (except the coronal button that is made by trabecular dentine), the cusps have a variable number of consistently vertical cristae and, finally, the most remarkable feature of Triodus is an elongated median cusp that in some species reach almost the same length of the lateral cusps, which are evidently different from the Rio do Rasto specimens described here.
The dropped shaped to triangular shaped tooth base of Mooreodontus differs from X. ragonhai tooth base, which is almost rounded or oval shaped and the comparison with Wurdigneria will be dealt with latter.

The emended diagnosis of Xenacanthus presented by Hampe (2003) and the summary of the genus of Ginter et al. (2010), allowed for the determination that the Rio do Rasto specimens here described belong to this genus, sharing almost all features presented by these authors. These shared features comprise: cusps usually lanceolate in cross-section and with smooth lateral edges; coronal button varying in size but being predominantly circular in shape; shaft developed; constantly large number of nutrient foramina perforating the base; basal tubercle with variable degrees of basal depression; cusps composed by orthodentine surmounting a base of trabecular dentine.

The species Xenacanthus ragonhai sp. nov. diverges from the other known species of Xenacanthus on the presence of a fine enameloid covering on the teeth, in the presence of a few smooth cristae of enameloid on the lateral cusps and the trabecular dentine overlaping externally the orthodentine on the basal portion of the lateral cusps, which are peculiar features of the new species.

The comparison between Xenacanthus ragonhai sp. nov. with other Brazilian xenacanthids that closely resemble this species is presented below.

X.ragonhai sp. nov. differs from Xenacanthus pricei Würdig-Maciel 1975 due to the presence, in the latter, of smooth carinae on the entire edge of the cusps, coronal button and basal tubercle proportionally minor, few foramina on the aboral surface of the base, and finally, all known teeth of $X$. pricei are very small. Beyond these features, $X$. pricei is described for the Irati Formation (Late Artinskian according to Holz et al., 2010), so it is at least 8 M.y. older than $X$. ragonhai sp. nov. from the Rio do Rasto Formation (Wordian to Wuchiapingian). 
Another Brazilian species is Xenacanthus santosi Würdig-Maciel 1975, collected in the Caveiras Facies of Estrada Nova Formation of Rio Grande do Sul State. These beds are actually included in the Terezina Formation, Late Kungurian to Rodian, thus being a little older than the Rio do Rasto Formation specimens. The new species $X$. ragonhai diverges from $X$. santos $i$ by the presence, in the latter, of laterally compressed cups with smooth carinae on the lateral edges plus some branching cristae. The coronal button in $X$. santosi does not present a prominent edge, and in the connection with the base does not have a notch nor a shaft, which are evident in X. ragonhai sp. nov.

Würdig-Maciel (1975) considered in the diagnosis of $X$. pricei and $X$. santosi some unreliable features, such as cusps with different sizes and inclinations, which could be related to distinct positions in the jaw, occlusal wearing and taphonomical abrasion as already mentioned by Ragonha (1984a) and Richter (2005).

Some other Brazilian xenacanthid species were presented for the São Paulo State, Xenacanthus angatubensis, X. camaquensis, X. ferrazensis, X. santaritensis and $X$. taquaritubensis all described by Ragonha (1984a) for the Corumbataí Formation (= Serra Alta and Terezina formations sensu Holz et al. 2010). These five species were not formally published, remaining as nomina nuda. In spite of this, Ginter et al. (2010) indicate that these unpublished species could have affinities with the Middle to Upper Triassic Mooreodontus genus based on the fact that Ragonha (1984b) attributed a Carnian age (Triassic) to the Corumbataí Formation and Mooreodontus is the only known post-Paleozoic species of Xenacanthidae. However, this seems to be a historical mistake, since it is now well known that Corumbataí Formation has an estimated age between Lower to Middle Permian (Kungurian to Rodian sensu Holz et al. 2010).

Richter (2005) describes Wurdigneria obliterata also for the Terezina Formation (Rio Grande do Sul State). Xenacanthus ragonhai sp. nov. differs from $W$. obliterata because the latter have cusps laterally compressed distally, smooth carinae on the cusps edge, pulp cavity obliterated by osteodentine, absence of enameloid covering the lateral cusps and also the lack of trabecular dentine overlapping the orthodentine of the basal portion of the lateral cusps.

One of the most remarkable diagnostic feature of Wurdigneria obliterata pointed out by Richter (2005) is the obliteration of the pulpar cavity by trabecular dentine which indicates affinities with Diplodoselachidae. Ginter et al. (2010) mentioned that Xenacanthus santosi could be merged in a new combination ?Wurdigneria santosi. However, this obliteration is not present in $X$. santosi and the other morphological features presented by Würdig-Maciel (1975), fits better with the emended diagnosis of the Xenacanthus genus proposed by Hampe (2003) and by Ginter et al. (2010), so this species could not belong to the genus Wurdigneria.

Concerning the paleoenvironment, in the type locality and stratigraphical horizon, X. ragonhai sp. nov. is associated with fossil plants, conchostraceans and actinopterygian remains. In the Serrinha Member, a short-snouted temnospondil amphibian also occurs (Barberena et al. 1985, Barberena and Dias 1998). This, in addition with the whole paleontological record, indicates continental and freshwater conditions for the entire Rio do Rasto Formation, as already proposed by Holz et al. (2010). Therefore, Xenacanthus ragonhai sp. nov. could represent another freshwater record for xenacanthid sharks.

\section{ACKNOWLEDGMENTS}

The authors acknowledge Carolina Pauliv Garcia for helping during the field work, and Eduardo S. Suzuki for helping during the preparation of this manuscript. The Museu de Ciências Naturais (MCNSCB-UFPR) in memoriam of professor Euclides Fontoura da Silva Junior for providing most of the necessary infrastructure and equipment needed to the execution of this work. Positivo University, 
Unioeste University, Fundação Zoobotânica do Rio Grande do Sul and LaFMA-UFPR for providing the microscopes and stereomicroscopes to take photos of the specimens. This research was made possible with the financial support (Master grant) from Conselho Nacional de Desenvolvimento Científico e Tecnológico (CNPq) to Victor Eduardo Pauliv.

\section{RESUMO}

O registro brasileiro dos Xenacanthiformes inclui dentes e espinhos cefálicos encontrados nas bacias do Parnaíba, Amazonas e Paraná. Este trabalho descreve uma nova espécie de Xenacanthidae, coletada em um afloramento do Membro Serrinha da Formação Rio do Rasto (Wordiano ao Wuchiapingiano), Bacia do Paraná, Município de Jacarezinho, Estado do Paraná. Os dentes da nova espécie são bi ou tricuspidados e a superfície aboral apresenta uma suave concavidade e um tubérculo basal arredondado. A superfície coronal apresenta um botão coronal semiesférico e subcircular, além de duas cúspides laterais principais e uma central (quando presente) com menos de um quinto do tamanho das cúspides laterais em sua porção labial. As cúspides laterais são assimétricas ou simétricas, arredondadas em corte transversal, lanceoladas em corte longitudinal, carenas laterais e serrilhas laterais ausentes, e com suaves cristas de enamelóide. Em microscopia óptica os dentes apresentam base composta por dentina trabecular (osteodentina), enquanto que as cúspides são compostas por ortodentina, e os canais pulpares não são obliterados por dentina trabecular. A assembléia fóssil no mesmo nível estratigráfico e na Formação Rio do Rasto como um todo indica mais um registro de água doce para os tubarões xenacantídeos.

Palavras-chave: Permiano, Xenacanthimorpha, Xenacanthidae, Xenacanthus, dentes de tubarão.

\section{REFERENCES}

ALves YM 2010. Los vertebrados fóssiles del Paleozoico y Mesozoico del Estado de Tocantins (Brasil): A preliminar síntesis. Caminhos Geogr (UFU) 11: 224-236.

Alves YM, SouZA FEF, MARINHO TS AND CANDEIRO CRA. 2008b. Paleoictiofauna da Formação Pedra de Fogo (Permiano Inferior) do Estado do Tocantins. Paleontol Destaq Ed especial maio, p. 26.
Alves YM, TAVARES LFS, SOUZa FEF, Silva KR, Almeida LO AND CANDEIRO CRA. 2008a. Vertebrate Paleontology of Parnaíba Basin (Paleozoic) in southern Maranhão state and northern Tocantins state, Brazil. Paleontol Destaq Ed especial maio, p. 27.

BARBERENA MC, ARAúJO DC. AND LAVINA EL. 1985. Late Permian and Triassic tetrapods of Southern Brazil. Nat Geog Res 1: 5-20.

BARBERENA MC AND DIAS EV. 1998. On the presence of a short-snouted rhinesuchoid amphibian in the Rio do Rasto Formation (Late Permian of Paraná Basin, Brazil). An Acad Bras Cienc 70(3): 465-468.

CAMPANElli LC AND Fernandes MA. 2008. Análise da eficiência de diferentes ácidos no processo de remoção dos restos fossilíferos de peixes, em rochas permianas da Formação Corumbataí (Rio Claro - SP). Paleontol Destaq Ed especial Maio, p. 59.

Chahud A AND Petri S. 2008. Chondrichthyes no Membro Taquaral, base da Formação Irati, no centro Leste do Estado de São Paulo, Brasil. Rev Geol UFC 21(2):169-179.

Chahud A AND Petri S. 2009. Novos Xenacanthidae (Chondrichthyes, Elasmobranchii) da Base do Membro Taquaral, Formação Irati, Permiano da Bacia do Paraná. Rev Inst Geol 30(1/2): 19-24. doi: 35442002 miolo.indd

Chahud A AND Petri S. 2010. O tubarão Taquaralodus albuquerquei (Silva Santos, 1946) do Membro Taquaral (Permiano, Formação Irati) no Estado de São Paulo. Acta Biol Par 39(1-2): 1-17.

DIAS EV. 1996. New fish (Actinopterygii, Platysomidae) from the Upper Permian of Paraná Basin, Brazil. Ameghiniana 33: 463 .

DufFin CJ, Richter M AND NeIS PA. 1996. Shark remains from the Late Carboniferous of the Amazon Basin, Brazil. Neues Jahrb Geol P-M 1996(4): 232-256.

Figueiredo AEQ, Cisneros JC, Dietzien-dias PC AND LIPARINI A. 2008. Una nueva localidad con peces fósiles en La Formación Rio do Rasto (Pérmico: Guadalupiano), Rio Grande del Sur, Brasil. In: III CONGRESO LATINOAMERICANO DE PALEONTOLOGÍA DE VERTEBRADOS Neuquén, Argentina. In: Libro de Resúmenes, p. 93.

GINTER M. 2004. Devonian sharks and the origin of Xenacanthifomes. In: ARRATIA G, WILSON MVH AND CLOUTIER R (Eds), Recent Advances in the Origin and Early Radiation of Vertebrates, München: Friedrich Pfeil, p. 473-486.

Ginter M, Hampe O AND Duffin C. 2010. Chondrichthyes Paleozoic Elasmobranchii Teeth. In: SCHULTZE PH (Ed), Handbook of Paleoichthyology, 3D. München: Verlag Dr. Friedrich Pfeil, 168 p.

GORDON JR O. 1947. Classificação das formações gonduânicas do Paraná, Santa Catarina e Rio Grande do Sul. Boletim DNPM-DGM 1: 374-385.

HAMPE O. 1988. On the Dentition of Orthacanthus (Chondrichthyes, Xencanthida) Upper CarboniferousLower Permian. Palaont Z 62(3-4): 285-296. 
HAMPE O. 1991. Histological investigations on the fossil teeth of the shark-order Xenacanthida (Chondrichthyes: Elasmobranchii) as revealed by fluorescence microscopy. Leica Sci Tech Inform 10(1): 17-27.

HAMPE O. 2003. Revision of the Xenacanthida (Chondrichthyes: Elasmobranchii) from the Carboniferous of the British Isles. Trans R Soc Edinburgh: Earth Sci 93: 191237. doi:10.1017/S0263593300000419

Holz M., FrançA AB, SOUZA PA, IANNUZzi R AND RoHn R. 2010. A stratigraphic chart of the Late Carboniferous/ Permian succession of the eastern border of the Paraná Basin, Brazil, South America. J South Am Earth Sci 29: 381-399. doi:10.1016/j.jsames.2009.04.004

JOHNSON GD. 1999. Dentitions of Late Palaeozoic Orthacanthus species and new species os Xenacanthus (Chondrichthyes: Xenacanthiformes) from North America. Acta Geol Pol 49(3): 215-266.

LAVINA EL. 1991. Geologia sedimentar e paleogeográfica do Neopermiano e Eotriássico (Intervalo Kazaniano-Scithiano) da Bacia do Paraná. Unpublished Ph.D. thesis. Programa de Pós-Graduação em Geociências, Universidade Federal do Rio Grande do Sul, Porto Alegre. 333 p. (Unpublished).

LONG JA. 2011. The rise of fishes: 500 million years of evolution, $2^{\text {nd }}$ Edition. Baltimore: John Hopkins University Press, 287 p.

Mendes JC. 1967. The Passa Dois Group (The Brazilian Portion of the Paraná Basin). In: BIGARELLA JJ. BECKER RD AND PINTO JD (Eds), Problems in Brazilian Gondwana Geology, Curitiba: Papelaria Max Roesner Ltda, 344 p.

MINEROPAR. 2006. Mapa Geológico do Estado do Paraná. Mineropar. http://www.mineropar.pr.gov.br/arquivos/Files/2 Geral/Geologia/PDF_Mapa_Geo_650000/Mapa_Geologico_ PR_650000_2006.pdf.

Moy-THomas JA And Miles R. 1971. Palaeozoic Fishes, $2^{\text {nd }}$ ed., London: Chapman and Hall Ltd., 259 p.

Pauliv VE, Dias EV And Sedor FA. 2009. Espinhos de Sphenacanthus (Chondrichthyes) da Formação Rio do Rasto no Estado do Paraná. Paleontol Destaq 63: 64.

Pauliv VE, Dias EV AND SEdor FA. 2010. Ocorrência de Xenacanthida (Chondrichthyes: Elasmobranchii) para o Membro Serrinha da Formação Rio do Rasto (Bacia do Paraná) no Estado do Paraná. Paleontol Destaq Ed especial julho, p. 22.

Pauliv VE, Dias EV AND Sedor FA. 2012. A New Sphenacanthid Species (Chondrichthyes, Elasmobranchii) from the Rio do Rasto Formation (Paraná Basin), Southern Brazil. Rev Brasil Paleontol 15(3): 243-250. doi:10.4072/ rbp.2012.3.01

Ragonha EW. 1978. Chondrichthyes do Membro Taquaral (Formação Irati) no Estado de São Paulo. Master dissetation. Instituto de Geociências, Universidade de São Paulo, São Paulo, 65 p. (Unpublished).

RAGONHA EW. 1984a. Taxionomia de dentes e espinhos isolados de Xenacanhodii (Chondrichthyes, Elasmobranchii) da Formação Corumbataí. Considerações Cronológicas e Paleoambientais. Ph.D. thesis. Instituto de Geociências, Universidade de São Paulo, São Paulo, 166 p. (Unpublished).
RAGONHA EW. 1984b. Taxionomia de dentes e espinhos isolados de Xenacanhodii (Chondrichthyes, Elasmobranchii) da Formação Corumbataí. Considerações Cronológicas e Paleoambientais. Rev Brasil Geociênc 14(3): 179.

RAgONHA EW. 1986. Espinho cefálico de Xenacanthus (Chondrichthyes, Elasmobranchii) da Formação Corumbataí, Bacia do Paraná-Estado de São Paulo. In: XXXIV CONGRESSO BRASILEIRO DE GEOLOGIA, Goiânia, Brasil. Anais (1): 533-538.

RAGONHA EW. 1989a. Ictiodorielite de Base Bulbosa. Evidências de um possível processo articulatório. In: XI CONGRESSO BRASILEIRO DE PALEONTOLOGIA, Curitiba, Brasil. Anais, p. 177-181.

Ragonha EW. 1989b. Placas dentárias de Dipnoi no Grupo Passa-Dois (P-Tr) da Bacia do Paraná. Apreciações ambientais, climáticas, cronológicas e estratigráficas. In: XI CONGRESSO BRASILEIRO DE PALEONTOLOGIA Curitiba, Brasil. Anais, p.195-206.

Ragonha EW. 1990. Presença de Xenacanthus na Formação Rio do Rasto, Estado do Paraná. An Acad Bras Cienc 62(1): 104.

Richter M. 2005. A new xenacanthid shark (Chondrichthyes) from the Terezina Formation, Permian of the Paraná Basin, Southern Brazil. Rev Bras Paleontol 8(2): 149-158.

RoHN R. 2001. A estratigrafia da Formação Teresina (Permiano, Bacia do Paraná) de acordo (com furos de sondagem entre Anhembi (SP) e Ortigueira (PR). Ciência-Técnica-Petróleo, Petrobrás, Seção Exploração de Petróleo 20: 209-218.

Silva-SANTOS R. 1946. Duas novas formas de Elasmobrânquios do Paleozóico do Meio Norte, Brasil. An Acad Bras Cienc 18(4): 281-287.

Silva-SAntos R AND SAlgado MS. 1970. Um Espinho de Xenacanthus do Carbonífero do Estado do Maranhão. An Acad Bras Cienc 42(2): 223-227.

SOUZA FES, Alves YM, MARINHO TS AND CANDEIRO CRA. 2008. Diversidade de Chondrichthyes da Formação Pedra de Fogo (Permiano Inferior) Bacia do Parnaíba. Paleontol Destaq Ed especial maio, p. 192.

Toledo CEV, BERTINI RJ AND SANTUCCI RM. 2005. Nota preliminar sobre uma ocorrência de Xenacanthiformes na Formação Irati do Estado de São Paulo, Grupo Passa Dois, Permiano da Bacia do Paraná. In: XIX CONGRESSO BRASILEIRO DE PALEONTOLOGIAE VICONGRESSO LATINO AMERICANO DE PALEONTOLOGIA. Aracaju, Sergipe. Boletim de Resumos. Published in cd-rom.

TURNER S AND BURROW CJ. 2011. A Lower Carboniferous Xenacanthiform Shark from Australia. J Vert Paleont 31(2):241-257. doi:10.1080/02724634.2011.550359

WÜRDIG-MACIEL NL. 1975. Ichthyodontes e Ichthyodorulitos (Pisces) da Formação Estrada Nova e sua Aplicação na Estratigrafia do Grupo Passa-Dois. Pesquisas 5: 7-85.

ZANGERL R. 1981. Chondrichthyes I - Paleozoic Elasmobranchii. In: SCHULTZE HP (Ed), Handbook of Paleoichthyology, Stuttgart-New York: Gustav- Fischer Verlag, vol. 3A, 115 p. 